\title{
SHARPENING THE PENCIL
}

\section{A visual journey towards the outlines of drawing as an autoethnographical method}

\section{Marika Tervahartiala}

The presented research started as a drawn autoethnography focusing on drawing as a method. Surprisingly, outlining the autoethnographic drawing process revealed it to not only be the drawer's autoethnography but also the drawing processes autoethnography of itself and then, in turn, about the drawer. As I draw, the autoethnography, my processes, the drawing sketches me into being. These mutual acts gave rise to an attempt at a methodological approach where the drawing is an inseparable part of all the stages and iterations of the visual autoethnographic research process. Post-disciplinary as well as post-structuralistic approaches are needed to unveil and enlighten the possibilities of drawing as methodology and theory as practice (Irwin and Springgay 2008, 106). The autoethnographic drawing as a methodology is located within the umbrella of autoethnographic methodology that uses the researcher's personal experience as data to describe, analyse and
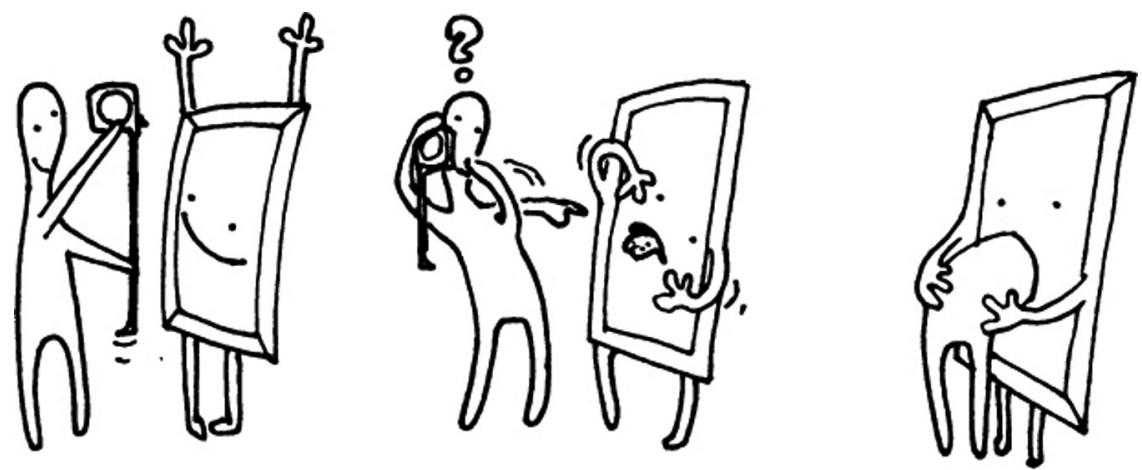

FIGURE 7.1 Drawing by Marika Tervahartiala, 2019. Copyright: Marika Tervahartiala 
understand cultural experience. This specific visual form of self-narrative places these two autoethnographic selves - the drawer and the drawing - within social as well as visual contexts and discourses.

This chapter aims to explore how autoethnographic drawing can be much more than just another visual method to be explored. It draws out drawing as a research methodology and lets the drawing to be[come] (Varto 2017, 21). Thus, the drawing is the methodology and the subject to be studied. The Drawing is presented as a real boundary bender in/of the line and within the lines: exploring the possibilities of a post-disciplinary methodology, fluently and shamelessly combining visual autoethnography, visual arts, even some scholarly comics and artistic research, while also flexing itself with a hint of art educational and transformative research. Drawing knows itself better than academic writing can describe it, thus the drawing is always more than language and words can (ever) know.

In this chapter, drawing is capitalized when referred to as a character, a "knower" or a mode of knowing that exceeds the researcher's abilities and capacity to know. Consequently, the agency in this chapter is shared. Even as a singular autoethnographer, I am not alone on my research journey, as the Drawing has uncovered itself as an emergent and active agent. It has repeatedly and resiliently withdrawn from being a research object and instead insisted on its full existence as an equal co-researcher in the autoethnographic process. As a general principle explaining my relationship with Drawing, I follow the advice of Carolyn Ellis "to rather show than tell" (2019, oral communication). Telling about the autoethnographic drawing (verb) cannot be anything but incomplete and present partial stories due to drawing's flow-like quality and insistence on stretching and bending subjectivities and boundaries of being and knowing.

A growing number of researchers from various fields have recently become interested in visuals: as material and method, produced and used by scholars. "Visuals" include a variety of graphic-based processes and productions such as drawings, comic art/scholarly comics (Kuttner, Sousanis, and Weaver-Hightower 2017; McCloud 1993, 2006), graphic novels (Sousanis 2015b), visual journaling (Shields 2016), sketchbooks and illustrations. Drawing fits into numerous contradicting and overlapping disciplines and areas of contemporary study (Theron et al. 2011, 19). As a research method, drawing is a true post-disciplinary nomad, finding its home wherever the line is drawn (pun intended): fluently sketching itself among other visual methods for example in anthropology and ethnography (Alfonso et al. 2004; Ingold 2007, 2010, 2011; Pink 2007a; 2007b). One can find it in educational research as a/r/tography (Cahnmann-Taylor and Siegesmund 2008; Irwin and Springgay 2008) as well as in health and social science(s) (Theron et al. 2011). It can be spotted in the research of art to research through art and art-based, arts-informed, even artistic research (Knowles and Cole 2008; Mannay 2016; Mäkelä and O’Riley 2012; Mäkelä and Routarinne 2006; Rose 2001; Varto 2013, 2017; Sullivan 2008; Chenail 2008; Bochner and Ellis 2003; Douglas and Carless 2018; Guillemin 2004; Literat 2013; Sava and Nuutinen 2003; Leavy 2018). This explorative chapter on the methodology and ethics of 
autoethnographic drawing aims to blur the current [drawn] lines between disciplines as allocating or limiting drawing precisely to a specific academic discourse which only disrupts it.

Drawing that corresponds to autoethnography has the quality of being simultaneously used as a method and a methodology. It could simply be the way to present and illustrate research outcomes, but in this chapter I focus on arguing that autoethnographic drawing can "contribute to new knowledge and offer new ways of imagining and encountering the world" as Duxbury $(2009,97)$ claims about art in general. Constructing my claims, I rely on previous research as well as my own experiences as a practitioner, as an autoethnographer, a drawer and a combination of both. Tongue in cheek, I propose that, by sharpening my pencil, I contribute to the scholarly conversation exploring the possibility of autoethnographic drawing as a methodology.

\section{Methods, ontological fluidity and the emergent epistemology of drawing}

In autoethnographic drawing, the method and methodology, together with epistemology, are interrelated. And although there may be multiple possibilities for each, if used as an epistemological orientation, each element is deeply intertwined. As a result of this, I aim to elucidate the epistemology and ontology of autoethnographic drawing. By outlining the epistemological standpoint, the framework of possibilities can be identified.

To define drawing, I use the concept of drawing instead of visual journaling, sketching or doodling (e.g. Azevedo and Ramos 2016, 143; Tokolahi 2010, 161; Heath, Chapman, and The Morgan Centre Sketchers 2018). Many visual ethnographers use these terms fluently and interchangeably side by side without asking the question "Who owns the words we use?" (Swanson 2008, 89) or without making significant conceptual, or theoretical distinctions between them. The concept of autoethnographic drawing was chosen for my research because it is more related to intentionality than the words "sketching" or "doodling". At least my sketching tends to be messy to the point that it turns into abstract and unfocused doodling. They both are random try-outs, visual splashes of ongoing processes, sometimes done to spend time or amuse others or myself. With the autoethnographic drawing, as I perceive the method, there is always an aim to end up with a finalized picture to the level of completion that it can also be "understood" by those other than the drawer. However, the practical steps of my drawing process are beside the methodological point.

More broad artistic approaches, such as photography, video and sound, have become popular in ethnographic research in the 21st century. These approaches have been actively developed, and their methodological and ethical challenges widely discussed (Alfonso, Kurti, and Pink 2004; Pink 2007a; 2007b; Mannay 2016; Knowles and Cole 2008; Hughes-Freeland 2004; MacDougall 1997). Among the wide and expanding range of visual methods and forms of 
representation, drawing has only received little attention in scholarship. Drawing as a[n auto]ethnographical research method and especially as a methodological construction is unexplored and relatively under-theorized with only a few examples to mention (e.g. Theron et al. 2011; Weber 2008; Literat 2013; Azevedo and Ramos 2016). Visual autoethnographies (e.g. Scarles 2010) use other methods/methodologies than drawing, mostly photography and video.

Every academic discipline has its ontological sphere (Varto 2017, 62-64), where research phenomena are to be understood and where their existence is accepted and expected. Usually, besides this sphere, the phenomena become blurry, losing their distinctive characteristics (Varto 2017, 62). I claim that drawing is an emergent method and methodology, an event and an entity, in the epistemology of a constant state of becoming. When utilized, harnessed and respected to the potential of its emergent being as an oddity and a chameleon spirit, it can turn every disciplinary hue to its own, with no harm done to its assigning itself fluently to the post-disciplinary transformation. I see drawing as "a living process for communicating and understanding" (Four Arrows 2008, 6). To $\mathrm{me}$, it is also an ontology, a being.

Due to being an ontology, in the initial stages of researching autoethnographic drawing quite often resembles fumbling with a marker pen in the dark. Especially before the process begins, it is hard to point out what should be [re]searched and even more challenging to identify the tools for this quest (Varto 2017, 23). The actual drawing process[es] brings along the needed light and clarity to the focus. As Swanson $(2008,84)$ in her arts-based research points out: "A researcher can never be absolutely sure, only guided towards what she believes to be the way ahead". To best describe this, I claim that autoethnographic drawing could be compared to GPS-navigation: unless you move (your marker), you will never find out if you are going in the right direction. Drawing as artistic research seizes scrabbling, scribbling, drifting and walking the track: as these are all elementary in grasping the essential part of the process that is creative and evocative. The autoethnographic drawing process is the operationalization of this epistemological standpoint: by drawing, I begin to be, understand and know.

As is true of all scholarship, locating one's work within a methodological community or communities is crucial (Theron et al. 2011, 21). I trace my study alongside ethnographic, and specifically autoethnographic, methodologies. The analysis of visual imagery and exemplary texts on the interpretation of visual materials are well known. The critical visual methodology (Rose 2001) and visual ethnography are useful methodological perspectives, but they cannot be applied for developing the methodology of autoethnographic drawing. This research gravitates towards and emerges from exploratory, more artistic research methodologies. Thereby I operate within a creative paradigm of artistic research methodologies.

The autoethnographic drawing process is reluctant to be reduced into a research instrument and the continuous drawing process resists being formalized into a set of procedures or prescriptions (Swanson 2008, 89). Shifting from one discipline to another, whether inter-, trans- or post-disciplinary, does not suffocate drawing as 
much as if drawing is subordinated from a way of knowing (e.g. Bochner and Ellis 2003, 508), communicating and understanding (Four Arrows 2008, 6). Drawing that is diminished to an instrument or a plain procedure loses its unique intuitive and creative potential of [un] knowing, not-knowing and [re]creating the negative capability (Bion 1980, 11).

I argue that the autoethnographic drawing does not accommodate any toollikeness as a method. Rather, it has a tendency to unfold and uncurl, colour outside and over the lines, to grow and flow into a methodology. The autoethnographic drawing by being simultaneously the researcher and the Drawing generates creative research processes expanding beyond researcher's cognition and logic. Understandably, rendering visual research process in a form of a textual methodological chapter is far from untroublesome (see also Swanson 2008, 85). To explore this, I turn to post-structuralism. Post-structuralism considers the research of the underlying structures itself as a cultural product. Therefore, studying the underlying structures cannot be anything but subjective and subject to prejudices and misinterpretations. In addition, the analysis of drawing itself (the visible) is insufficient to provide understanding about autoethnographic drawing as a dialogical process and product as well as the mutual being of one (researcher) and the other (Drawing).

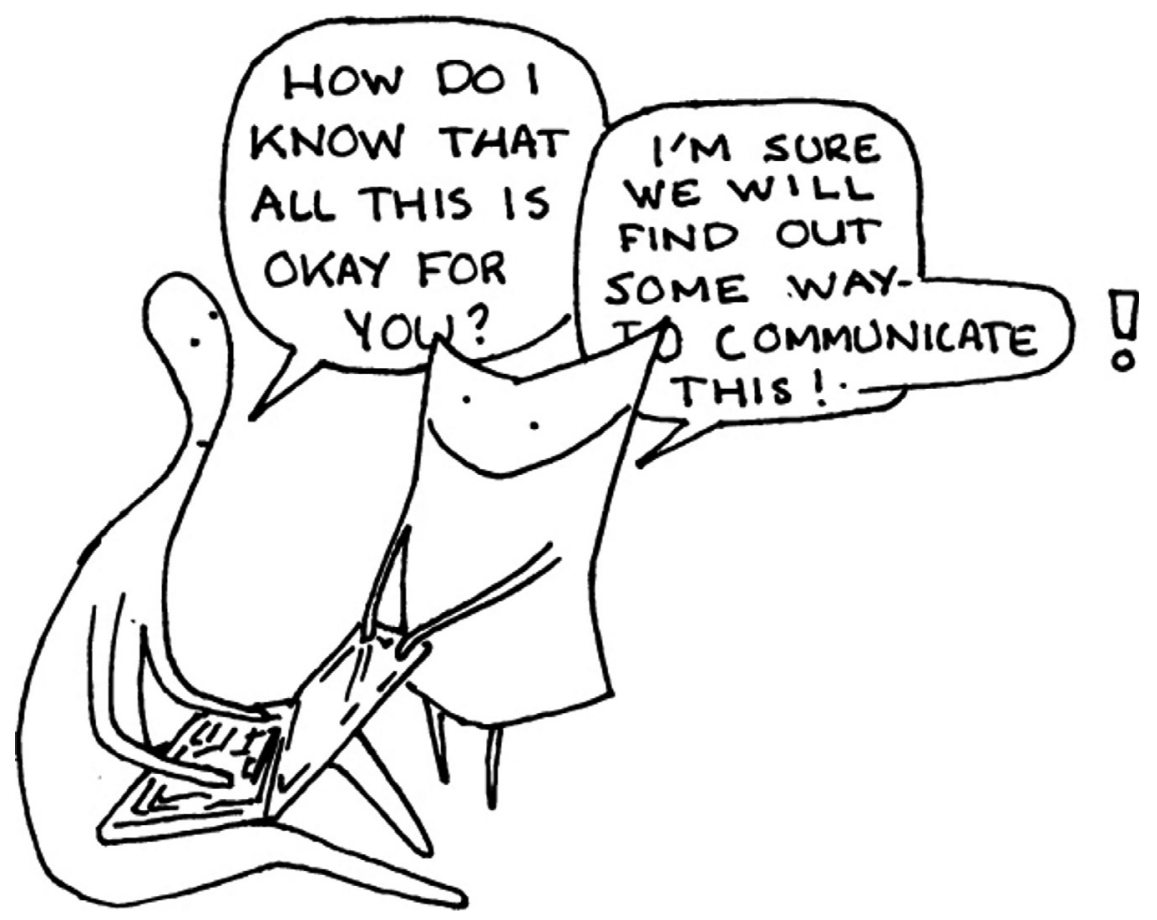

FIGURE 7.2 Drawing by Marika Tervahartiala, 2019 Copyright: Marika Tervahartiala 


\section{Drawing the line, drawing as an active agent and autoethnographical authority}

Bruner claims our thoughts are associated with and largely constituted by images (1984). The Drawing is at least as much the creator of a drawer than the drawer is the creator of a drawing. Based on Baudrillard (1988, as cited in Weber 2008, 43), Weber claims: "images themselves act as objects and take on lives of their own, with no single object beyond the signifier as primary referent.... An image can thus be "the thing itself - the object of inquiry". I argue the autoethnographic drawing to be even more than "the thing itself". The Drawing as an active being is beyond "immutable" (Weber 2008, 43) or "object". Once in existence or partially imagined, its independence or authority cannot be oppressed, but it is a "living information system" (Four Arrows 2008, 2) and an entity. The Drawing is also a non-human "personality" $(2008,6)$ whose knowledge exceeds what I can articulate, and which I have to recognize and respect.

Drawing a line with a marker pen is not a moment of mark nor creation, but a visible continuation of a Drawing's becoming. We humans can imagine, dream and see images with our eyes (wide) shut (Weber 2008, 41). I see, visualize and imagine and understand before I think and, therefore, the Drawing seems to always to be ahead of me (Weber 2008, 41; Berger 1972). The emergent and processual drawing, its dialogical and multidirectional entities deny the autoethnographer's possibility to claim creator status. Due to the emergent and eventing nature of the autoethnographic drawing, it cannot be researched "as such" - by itself. Therefore, making autoethnographical observations on its effects and influence on me, the drawer, is needed, and the process of doing and generating and sharing the Drawing so that the process can be studied as a whole.

Actors share the experience of the role playing the actor instead of the actor playing the role. Autoethnographic drawing comes close to this well-recognized phenomenon: the Drawing (act) seems to be playing [drawing] me and vice versa. Occasionally, the blank page of the sketchbook becomes a stage-like space due to the performative nature of drawing. In the line-making act, the "becoming" of the Drawing is visible. This becoming continues in following perceptual processes. These further becomings can be understood through multiple orientation points: the drawer, the drawing and the relationship(s) and the reader/viewer [be]come [together] with, within and for the drawing or their theme.

In replacing hierarchies and existing power structures like: "Who was here in the first place? Where did it start and from whom? To whom does it belong?" I turn to post-structuralists like Deleuze and Guattari (1996). Their rhizomes seem to be opposite to hierarchies (Swanson 2008, 84-89; Irwin and Springgay 2008, 106). The dialogical space, the intention(s) of Drawing are always in motion, creating a complexity of multiple dimensions. Autoethnographic drawing is still "a terra incognita" that has not yet revealed in all its complexity "what it has, what it is, what it can do, and how it does it, and why" (Swanson 2008, 90). By engaging, I have asked it to come forth and partially reveal itself (see Swanson 2008, 90) and as an insightful partner, the drawing invites and insists that I do the very same. 
In the most subjective or self-serving terms, autoethnographic drawing serves as a tactic to reveal, understand and overcome the researcher's mental boundaries (Azevedo and Ramos 2016, 140). I usually draw "on the spot", for example in conferences, seminars and while reading reference materials. I [re]act by creating a visual commentary and/or giving visible form for my thoughts, associations, even attitudes and [pre-]assumptions. Drawing may twist, comment, observe or interpret ideas as well as the content I have the inner and/or visual dialogue with. I draw to be, to become and to understand. Autoethnographic drawing is instant: there is a sense of being in the zone - a feeling related to the concept of flow (Csikszentmihályi 1990). Making a drawing takes only a couple of minutes, but it creates a specific time-space for materializations of wandering and imaginative thought (Azevedo and Ramos 2016, 141). It also challenges this time-space specificity by questioning its limits and boundaries as it recreates itself unbound to its original time and space context.

\section{In uncertainty, nurture the trouble(d) and stay with the discomfort}

"Stay with the discomfort" is a commonly used piece of advice among autoethnographers (Carolyn Ellis 2019, oral communication). Anything somewhat tricky, hard to handle, unknown and the overall discomfort suggests: "Observe and research more closely!" This autoethnographically significant discomfort might be, for example hard-to-hear subconscious whispers and various signifying ruptures in the normally smooth drawing process. It can be a small notion that I change my mind in the middle of drawing; suddenly, I decide not-to-draw what intuitively came to my mind in the first place. Sometimes I sense shivering or faint doubts: "Is there something that I don't want to draw?" that I am not ready to understand or general alertness.

Azevedo and Ramos (2016, 143) mention "paralysis and hesitation in the act of drawing itself". Since I have been drawing all my life and researching it for a few of years, I no longer get "paralysed": hesitation, doubts and the unwillingness or inability to draw belong to my drawing process as a natural part. As in breathing, the pause between inhaling and exhaling, the gaps, stops and empty spaces are elemental in drawing (as a noun and a verb). For an autoethnographer, it is necessary to recognize that "gaps exist between what can be shown, seen or felt and what can be said" (Bochner and Ellis 2003, 507). These cracks and notknowing in (a) drawing are to be cherished as these fractures are also spaces for a reader/viewer to unknow and not-to-understand. I claim that drawing leaves more room for impartiality than words; the space between the lines is fertile soil for valuable uncertainty, wonder and curiosity.

The autoethnographic process of drawing usually includes several elements of flow, such us intense and focused concentration on the present moment, merging of action and awareness, and altered experience of time (usually time flies for me), but it also has features quite opposite to the flow. Instead of a loss of reflective selfconsciousness, some of the reflective and self-conscious elements are amplified by 
the Drawing, but not necessarily during drawing. Instead of a sense of personal control or agency over the activity, I experience fulfilment in the shared agency. There is an element of relief about the loss of personal control and, therefore, responsibility. Drawing and I flexibly blend the roles of a servant and a master, the observed and the observer. This is not a controllable knowing and far from getting fixed on the familiar and safe (Swanson 2008, 92).

While in the flow, the experience of the activity appears intrinsically rewarding, but the transformative autoethnographic drawing may as well be discomforting and cause friction. "The pain of letting go and just drawing goes against everything I know", describes Rambo $(2007,536)$ in her article about sketching as an autoethnographic practice. The feeling of losing oneself, becoming fragmented and fluid, a constant becoming or even the possibility of limitless openness are not always comfortable sensations. Hard as they are, to be appreciated just as dreaming and visions (having elements similar to drawing) are potentially valid sources to knowledge (Four Arrows 2008, 2). It is only by cyclically repeating the mental leap of faith of relying on drawing, that there is a primitive urge to control the process as it lessens but does not ever fully disappear. Experience or expertise of Drawing does not free me from still falling back to my inability to let go of control. Especially drawing in academic contexts repeatedly brings forth the requirement to (verbally) explain and validate the drawing (see also Rambo 2007, 537). It is still unsolved how it would be possible to academically praise the not-knowing and unknowing: "What if I do not know, but maybe the drawing does?"

This concept of "taking a leap of faith" has been troubling and explored by scholars (e.g. Duxbury 2009, 98). Whilst this chapter aims not to reach to the areas of transpersonal psychology or to the states of consciousness beyond the limits of the ego and personality, but it is clear that drawing brings along the transformational and intuitive. The faith in the process is usually based on the previous beneficial experiences of trusting on a creative method, as Clements states:

Transformative changes of heart - the training of ego to tolerate and support collaboration with liminal and spiritual sources - require a temporary suspension of critical thinking in order to access non-egoic input. Afterwards, the ego steps forward to integrate the new material into the study. (Clements 2011, 132)

A drawing autoethnographer does not need reconciliation for the controversial (or) discords (Swanson 2008, 87), but for the ego, which often too eagerly wants to grasp and control the pen.

The researcher's and Drawing's shared bidirectional autoethnographic "I" [eye/ (ai)] can have an intention to emerge as a storyteller and occasionally even a metalevel comic-character. Eventually, there cannot be any mediator for a drawer's "intention" as autoethnographic drawing is a fluid construction of diverse intentions and fluctuating intentionality. For the research to happen and the knowing to emerge, the drawer and the Drawing, which have a shared intention to emerge, become the lines; a picture to be seen and shared. Drawing is consciousness: 
In fact, consciousness is always about intentionality, directionality, agendas, positions or, if you will, a hypothesis. This comes from the experiential aspect of consciousness. Experience registers in our conscious awareness, the situation both as we undergo it, and as we relate to it. (Swanson 2008, 92)

Autoethnographic drawing accepts conflicting and overlapping readings. While the autoethnographer has to be willing to rely on Drawing, the reader/viewer is asked to give up on searching for the sole and "true" drawer's intentions. If the reader/viewer is able to let go and give up on the quest for sole intended message, possibilities for myriads of interpretative perspectives and, even processes of invention arise. They vary and multiply by every reader and reading and by shifting contexts, they create infinite kaleidoscopic possibilities, displacements and replacements. Thus, giving up becomes drawing out, the visual dialogue between the Drawing and the drawer then becomes a trialogue. The autoethnographical drawing desires to be a tempting invitation for a reader/ viewer to a dialogical journey as through this journey the Drawing gain infinite possibilities for more lives.

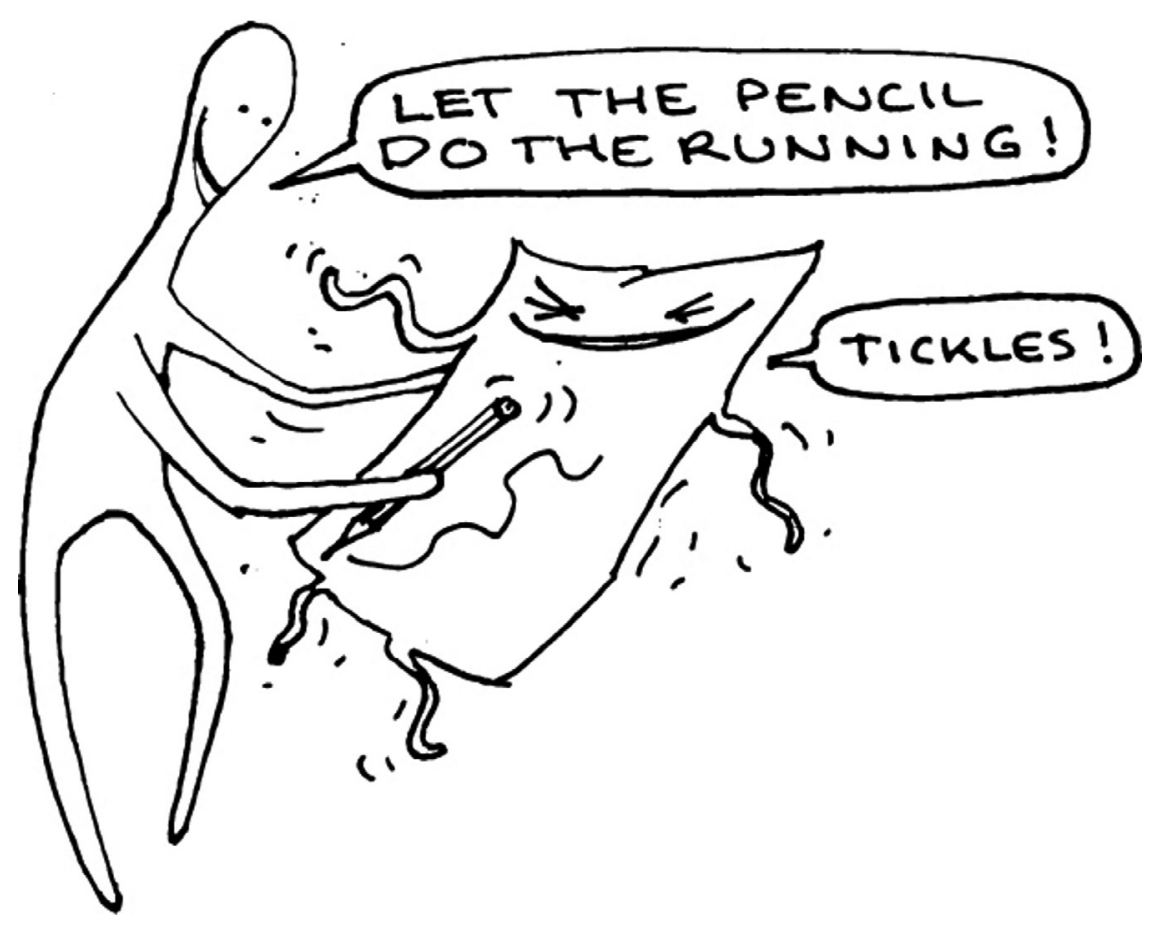

FIGURE 7.3 Drawing by Marika Tervahartiala, 2019. Copyright: Marika Tervahartiala 


\section{Linearity and binary classifications: time to draw (fight) back}

The path into the drawing is not linear: "creative work does not necessarily follow a linear process, nor adhere to objectivity and logic" (Bardsley 2018, 2). The arts are the symbiotic language of the subconscious, as Duxbury (2009, 97; see also Bardsley 2018) states. In this chapter, linear wordiness occurs in spite of the autoethnographic drawing's authority mainly due to the limitations of academic format. Deconstructing binaries of linear/non-linear, words/visuals, is not easily done, especially when the other autoethnographer, the simultaneous subject and object of the research (i.e. Drawing), is visibly absent from these pages. In addition, the sense of time and perceptions of time in autoethnographic drawing is hard to transmit through words, which are neatly marching in order, line after line, forming chapters, then turning into publications that dominate over visuals. Perceiving time in an autoethnographic drawing is engaging with the world in associative and flexible iterations.

Being non-linear and time unbound, autoethnographic drawing lets us into a pluralized epistomology. Drawing is somewhat akin to handwriting as it can be described with concepts related to the language: (visual) vocabulary, syntax and grammar. I prefer not to make distinctions between writing and drawing or between one kind of a drawing to another. Instead of categorizing and labelling, I prefer to blur and displace borders, disrupt dualisms between writing(s) and drawing(s).

The coherent or meaningful coming-together between visual drawings and the written text needs further research as processes of folding and unfolding images and text together are to be explored more closely. There might be times of unison, but the text and drawings are also purposely deconstructing each other. Focus on the fight on the hierarchy between visual and verbal attracts the reader into a deconstructive (reading) process(es), and thus remove the focus from the essential and elements and components of autoethnography (see also Four Arrows 2008, 2). Academic words alone cannot present a solid methodology of drawn autoethnography. Words and language alone or in dominant relation to visuals can create an illusion or a reproduction of a creative visual process, its description and even analysis, but they cannot be[come] it. Therefore, methodological knowing and outcomes will be bursting out [in]between the words and the lines. They are only hinting at the visual possibilities and the limitations of this chosen methodology.

I go along with Swanson's remark about research as an object not necessitating a final closure: in her research poetic enquiry is a process of continuous metaphoring, which also lies in the core of my autoethnographic drawing (Swanson 2008, 89). I claim that words can be drained from meanings more thoroughly than drawings. If a drawing is continuously refilled with meanings created by the viewer and the context, no number of words can drain a drawing of meanings. Barthes (1984, 38-39) considers the text as an anchor for the visual: the text loads the image. Instead of this one-way loading from text to image, a deconstructive approach applies, that text loads and unloads the drawings just as much the drawings (re/un)load the text. An essential element is the reader/viewer is an equal part of these ongoing processes of loading, constructing and deconstructing. 


\section{Drawing and drawings} in/of/and Academia

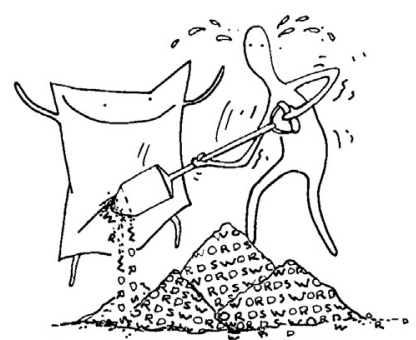

AS THE SAYING GOES: "Publish or

perish", but publishing research relying on

visuals can be challenging. Most publications rely on certain format(s) of academic text. Whether electronic or books, the publications are designed based on textuality: their layouts are fixed, and the amount, size and quality of the pictures is usually limited to a few small-scale black and white illustrative examples. It is obvious in laying out the pages that the composition of the pictures/text plays a significant role in conveying narrative and autoethnography. The meanings can be constructed as in comics: on, with and by the layout of the page(s) (Sousanis 2015a, 1-3; Eisner 1985; Sousanis 2012; Holmes 2008, 97). The fixed format of an academic paper in itself shares authority unequally between words and visuals. Only occasionally it is possible

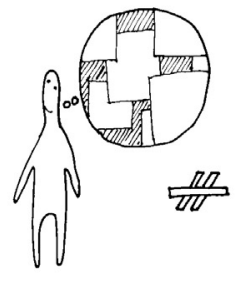
to modify these formats and give the leading role for visual [s], whether they are research material or otherwise. Any window of an opportunity usually belongs to the field of art and/or artistic research: maybe some new electronic form of publishing research including even video, sound or virtual reality - also commonly subordinated mediums. Based on new methods, methodologies and even forms of data, fundamental resharing of authority and power between words and visuals in the academic publications is needed in the near future. This is even more crucial considering Ellsworth's $(2005,156)$ : argument: "some knowings cannot be conveyed through language". Without autoethnographic drawings as equals to text, academia is losing forms of knowing that escape and slip through the language.

Academic formatting concretely renders the way drawings and words need to go hand in hand into something "nonsensical, illogical, and impossible to read", as Holmes $(2008,97)$ describes. It kills the Drawing. Like Holmes, I have also been struggling with the academic format, having no access to the visual design of the chapter or its page size and orientation, paper quality, lay-outs, margins, etc. Some of my autoethnographical drawings should be partnered with a particular piece of text, but not necessarily like the usual illustrations right before or after the text. To have their agency, they need their intervined presence, side-by-side, like partner in a dance: the drawings want to twirl around the text freely, flirt with it, and the other way around! The fluctuating relationship(s) and power struggle(s) between word and visuals should be clearly visible for the reader: the drawing(s) overlapping the text or willingly hiding behind it. If the particular drawings do not just as is their wish to have a dialogue, the beneficial differences of these mediums and their (opposing) voices and intentions is A be in the comparative or simul1 exchange with the text, they are diminished into indifferent illustrations. A clear power play, conscious or not, is against our autoethnographic voices. For autoethnographers the game is lost if the format of academic publishing just does not recognize Drawing's crucial ontological needs, especially the need to exist on its own terms. Then autoethnographic drawing is pushed into powerlessness, into margins and in between referential practices.

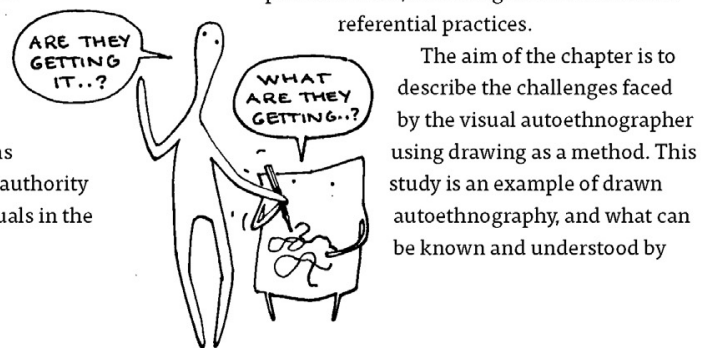

FIGURE 7.4 Drawings by Marika Tervahartiala, 2019, layout by Maria Manner. Copyright: Marika Tervahartiala 


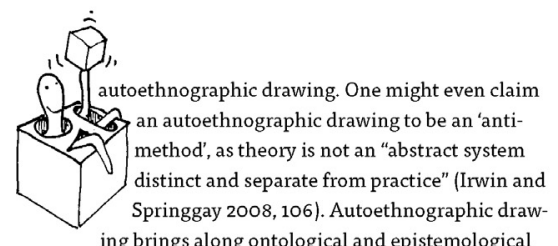
ing brings along ontological and epistemological questions concerning also other visual methods and their effectiveness. The potential of this perspective is that contemplating on the advantages and disadvantages of these themes may offer new perspectives to visual ethnographers to evaluate authority, entity and the artfulness of autoethnography.

Contemporary participatory visual methods are widely used in various fields to engage and empower the informants, influenced already by the early work of Paolo Freire (1970). The concept of participatory visuals methods is usually limited to the production stage of research and visual methods seem to be participatory only as long as the research is ongoing. Evoked imagination, producing images, or any other form

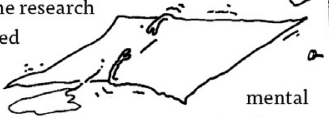
of visual thinking, participating in the dialogue with the visual(s) in a research report is usually not considered "participatory". As a drawing autoethnographer, I set an open question on how visual autoethnographic methods could be used to lure the reader/ viewer into participating in the visual knowledge production and processes of exchange even when presenting the 'finished' research.

Drawings are interrupting normalized academic formats and challenging to perceive freshly and differently the formats of scholarly publications. Any "sedimentation of the past research practices seeking 'certainty', 'closure' and 'control'" (Berry and Patti 2015, 265) fails and "These meanings therefore must be allowed to emerge in their own right, in their own 'light', according to their own idiosyncratic perspective and agenda, but also according to their own potentialities and potencies of meaning-making - not constrained by a priori definitions and theories of the meaning phenomenon that would restrict it in a narrow way, by prescribing its nature and reach before it is even investigated." (Swanson 2008, 90).

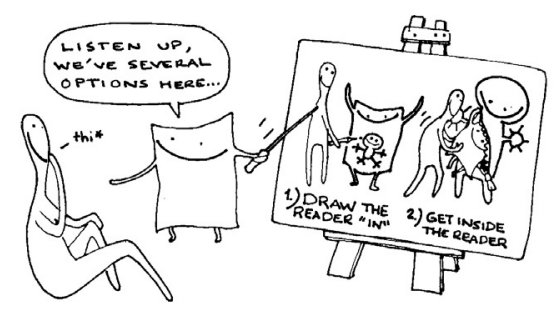

Altough this text is not composed in a manner that dignifies Drawing but as a mere presentation of words, the reader is to evaluate if I have managed to deepen and extend understandings and 'the usual terrain' (Swanson 2008, 87) of visual autoethnography with and about Drawing by drawing.

The Drawing is, and the drawings are, more than willing to be juxtaposed with the text and with the reader. On the contrary they favor being different, uncomfortable, displeasing, troubling, even entertaining! Autoethnographic drawing awakens Drawing and by this accepts uncertainty and uncomfortable in research and rather welcomes getting lost in narration with drawing (Berry and Patti 2015).

If image no longer illustrates the words

(Barthes 1984, 25), the freedom to create

A forms of representation that are in harmony with authentic experience, unique abilities

a and skills, is highly important. This is a significant and meaningful shift not only to the researcher but also to achieve the full potential of the research for/ with the readers (see Four arrows 2008, 4). Transformation in readers (Berry and Patty 2015, 265) may be too ambitious goal to draw out. An achievable aim may be to (re)imagine a more autoethnographic

$\sigma$ and holistic academic life, an inclusive life built on less restrictive ontologies and epistemologies. In the personal change, the development of insights and

b knowing would be more curious, explorative and open to trouble, discomfort, unknown and uncertain and as a result become more knowing, 'certain', accepting and limitless.

$b$

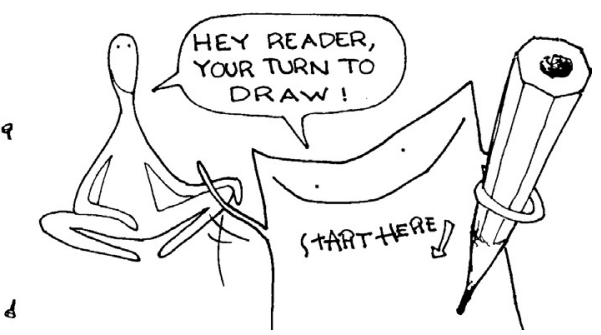

FIGURE 7.5 Drawings by Marika Tervahartiala, 2019, layout by Maria Manner. Copyright: Marika Tervahartiala 


\section{References}

Azevedo, A., and M. J. Ramos. 2016. "Drawing close - on visual engagements in fieldwork, drawing workshops and the anthropological imagination". Visual Ethnography 5 (1): 135-160. doi:10.12835/ve2016.1-0061

Alfonso, A. I., L. Kurti, and S. Pink, eds. 2004. Working Images: Visual Research and Representation in Ethnography. London: Routledge.

Anderson, R., and W. Braud. 2011. Transforming Self and Others Through Research: Transpersonal Research Methods and Skills for the Human Sciences and Humanities. New York: State University of New York Press.

Anderson, R., and J. Linder. 2019. "Spirituality and emergent research methods". In Routledge International Handbook of Spirituality and Society, edited by L. Zsolnai and B. Flanagan, 48-55. New York: Routledge. doi:10.4324/9781315445489

Bardsley, L. J. 2018. "Wholeness as a creative exploration of self". Survive \& Thrive: A Journal for Medical Humanities and Narrative as Medicine 4 (1): Article 16. https://repository.stcloud state.edu/survive_thrive/vol4/iss1/16

Barthes, R. 1984. Image Music Text. London: Fontana Paperbacks.

Berger, J. 1972 [2008]. Ways of Seeing. London: Penguin Design Series.

Berry, K., and C. J. Patti. 2015. "Lost in narration: Applying autoethnography". Journal of Applied Communication Research 43 (2): 263-268. doi:10.1080/00909882.2015.1019548

Bion, W. R. 1980. Bion in New York and São Paulo, edited by F. Bion. Perthshire: Clunie Press.

Bochner, A. P., and C. Ellis. 2003. "An introduction to the arts and narrative research: Art as inquiry". Qualitative Inquiry 9 (4): 506-514.

Bruner, E. M., ed. 1984. Text, Play, and Story: The Construction and Reconstruction of Self and Society. Washington, DC: The American Ethnological Society. https://doi.org/10.1525/a e.1985.12.2.02a00150

Cahnmann-Taylor, M., and R. Siegesmund, eds. 2008. Arts-Based Research in Education. Foundations for Practice. New York: Routledge.

Clements, J. 2011. "Organic inquiry. Research in partnership with spirit". In Transforming Self and Others Through Research: Transpersonal Research Methods and Skills for the Human Sciences and Humanities, edited by R. Anderson and W. Braud, 131-159. New York: State University of New York Press.

Chenail, R. J. 2008. “'But is it research?' A review of Patricia Leavy's method meets art: Arts-based research practice". The Weekly Qualitative Report 1 (2): 7-12.

Csikszentmihályi, M. 1990. Flow: The Psychology of Optimal Experience. New York: Harper \& Row.

Deleuze, G., and F. Guattari. 1996. What Is Philosophy? Translated by H. Tomlinson and G. Burchell, revised edition. New York: Columbia University Press.

Douglas, K., and D. Carless. 2018. "Engaging with arts-based research: A story in three parts". Qualitative Research in Psychology 15 (2-3):156-172. doi:10.1080/14780887.2018.1429843

Duxbury, L. 2009. "If we knew what we were doing". In SCOPE: Contemporary Research Topics (Art and Design), edited by L. Schmidt, A. Bramwell, and A. Kennedy, 1-8. New Zealand: Dunedin.

Eisner, W. 1985. Comics and Sequential Art. Tamarac, FL: Poorhouse Press.

Ellis, C., and A. Bochner. 2000. "Autoethnography, personal narrative, reflexivity: Researcher as subject". In The Handbook of Qualitative Research, edited by N. Denzin and Y. Lincoln, 733-768. Thousand Oaks, CA: Sage.

Ellsworth, E. 2005. Places of Learning: Media, Architecture, Pedagogy. New York: Routledge.

Four Arrows (Wahinkpe Topa), aka D. T. Jacobs, ed. 2008. The Authentic Dissertation. Alternative Ways of Knowing, Research, and Representation. London: Routledge. 
Freire, P. 1970. The Pedagogy of the Oppressed. New York, NY: Herder \& Herder.

Guillemin, M. 2004. "Understanding illness: Using drawings as a research method". Qualitative Health Research 14 (2): 272-289. doi:10.1177/1049732303260445

Heath, S., L. Chapman, and The Morgan Centre Sketchers. 2018. "Observational sketching as method". International Journal of Social Research Methodology 21 (6): 713-728. doi:10.1080/13645579.2018.1484990

Holmes, P. 2008. "A journey to praxis". In The Authentic Dissertation. Alternative Ways of Knowing, Research, and Representation, edited by Four Arrows (Wahinkpe Topa), aka D. T. Jacobs, 95-110. London: Routledge.

Hughes-Freeland, F. 2004. "Working images. Epilogue". In Working Images: Visual Research and Representation in Ethnography, edited by A. I. Alfonso, L. Kurti, and S. Pink, 201-214. London: Routledge.

Ingold, T. 2007. Lines. A Brief History. London: Routledge.

Ingold, T. 2010. "Drawing together: Materials, gestures, lines". In Experiments in Holism. Theory and Practice in Contemporary Anthropology, edited by T. Otto and N. Bubandt, 299-313. Oxford: Wiley-Blackwell.

Ingold, T. 2011. Being Alive: Essays on Movement, Knowledge and Description. London: Routledge.

Irwin, R. L., and S. Springgay. 2008. "A/r/tgraphy as practice-based research”. In Arts-Based Research in Education. Foundations for Practice, edited by M. Cahnmann-Taylor and R. Siegesmund, 103-124. New York: Routledge.

Knowles, G. J., and A. L. Cole, eds. 2008. Handbook of the Arts in Qualitative Research. Perspectives, Methodologies, Examples, and Issues. Los Angeles: Sage.

Koro-Ljungberg, M., T. Löytönen, and M. Tesar. 2017. "Irruptions. DataHoles". In Disrupting Data in Qualitative Inquiry. Entanglements with the Post-Critical and Post-Anthropocentric, edited by M. Koro-Ljungberg, T. Löytönen, and M. Tesar, 225-231. New York NY: Peter Lang Publishing.

Kuttner, P. J., N. Sousanis, and M. B. Weaver-Hightower. 2017. "How to draw comics the scholarly way. Creating comics-based research in the academy". In Handbook of Arts-Based Research, edited by P. Leavy, 396-422. New York: The Guilford Publications.

Leavy, P. 2018. Handbook of Arts-based Research. New York: The Guilford Press.

Literat, I. 2013. “'A pencil for your thoughts': Participatory drawing as a visual research method with children and youth”. IJQM, International Journal of Qualitative Methods 12 (1): 84-98.

MacDougall, D. 1997. "The visual in anthropology". In Rethinking Visual Anthropology, edited by M. Banks and H. Murphy, 276-296. New Haven: Yale University Press.

Mannay, D. 2016. Visual, Narrative and Creative Research Methods. Application, Reflection and Ethics. London: Routledge.

McCloud, S. 1993. Understanding Comics. Northampton, MA: Kitchen Sink Press.

McCloud, S. 2006. Making Comics. New York, NY: Harper.

Mäkelä, M., and T. O’Riley, eds. 2012. The Art of Research II. Process, Results and Contribution. Aalto University Publication Series, Art + Design + Architecture 11. Helsinki: Aalto Arts Books.

Mäkelä, M., and S. Routarinne, eds. 2006. The Art of Research. Research Practices in Art and Design. Publication series of the University of Art and Design Helsinki A 73. Helsinki: University of Art and Design Helsinki.

Pink, S., ed. 2007a. Visual Interventions. Applied Visual Anthropology. Studies in Applied Anthropology. New York: Berghahn Books.

Pink, S. 2007b. Doing Visual Ethnography. Images, Media and Representation in Research, second edition. London: Sage. 
Rambo, C. 2007. "Sketching as autoethnographic practice". Symbolic Interaction 30 (4): 531-542. doi:10.1525/si.2007.30.4.531

Rose, G. 2001. Visual methodologies. An Introduction to the Interpretation of Visual Materials. London: Sage.

Sava, I., and K. Nuutinen. 2003. "At the meeting place of world and picture: Between art and inquiry". Qualitative Inquiry 9 (4): 515-534. doi:10.1177/1077800403254218

Scarles, C. 2010. "Where words fail, visuals ignite: Opportunities for visual autoethnography in tourism research". Annals of Tourism Research 37 (4): 905-926.

Shields, S. S. 2016. "How I learned to swim: The visual journal as a companion to creative inquiry". International Journal of Education $\mathcal{E}$ the Arts 17 (8). http://www.ijea.org/v17n8/

Sousanis, N. 2012. "The shape of our thoughts: A meditation on \& in comics". Visual Arts Research 38 (1): 1-10. doi:10.5406/visuartsrese.38.1.0001

Sousanis, N. 2015a. "Grids and gestures: A comics making exercise". SANE Journal: Sequential Art Narrative in Education 2 (1): Article 8. https://digitalcommons.unl.edu/sane/ vol2/iss $1 / 8$

Sousanis, N. 2015b. Unflattening. Cambridge, MA: Harvard University Press.

Sullivan, G. 2008. "Painting as research: Create and critique". In Handbook of the Arts in Qualitative Research Perspectives, Methodologies, Examples, and Issues, edited by G. J. Knowles and A. L. Cole, 239-250. Los Angeles: Sage.

Swanson, D. 2008. "Breaking silences" (with J. Moran and E. Honan). In The Authentic Dissertation. Alternative Ways of Knowing, Research, and Representation, edited by Four Arrows (Wahinkpe Topa), aka D. T. Jacobs, 83-94. London: Routledge.

Theron, L., and C. Mitchell, A. Smith, and J. Stuart, eds. 2011. Picturing Research. Drawing as Visual Methodology. Rotterdam: Sense Publishers.

Tokolahi, E. 2010. "Case study: Development of a drawing-based journal to facilitate reflective inquiry". Reflective Practice 11 (2): 157-170. doi:10.1080/14623941003665976

Varto, J. 2013. Otherwise than Knowing. Ten Meditations on a Theme Inspired by Harri Laakso. Helsinki: Aalto University.

Varto, J. 2017. Taiteellinen tutkimus. Mitä se on? Kuka sitä tekee? Miksi?Helsinki: Aalto University.

Weber, S. 2008. "Visual images in research". In Handbook of the Arts in Qualitative Research. Perspectives, Methodologies, Examples, and Issues, edited by G. J. Knowles and A. L. Cole, 41-54. Los Angeles: Sage.

Zsolnai, L., and B. Flanagan, eds. 2019. The Routledge International Handbook of Spirituality in Society and the Professions. New York: Routledge. 